Bond and Equity Home Bias and Foreign Bias: an International Study

Rosanne Vanpée; Lieven De Moor

DEPARTMENT OF ACCOUNTANCY, FINANCE AND INSURANCE (AFI) 


\section{Bond and Equity Home Bias and Foreign Bias: an International Study}

Rosanne Vanpée

Hogeschool-Universiteit Brussel

KU Leuven

rosanne.vanpee@hubrussel.be

Lieven De Moor

Hogeschool-Universiteit Brussel

KU Leuven

lieven.demoor@hubrussel.be

May 3, 2012 


\begin{abstract}
In this paper we explore tentatively and formally the differences between bond and equity home bias and foreign bias based on one large scale dataset including developed and emerging markets for the period 2001 to 2010 . We set the stage by tentatively and formally linking the diversion of bond and equity home bias in OECD countries to the increasing public debt issues under the form of government bonds i.e. the supply-driven argument. Unlike Fidora et al. (2007) we do not find that exchange rate volatility has a greater impact on bond home bias than on equity home bias. We find, instead, that exchange rate volatility has a greater impact on bond foreign bias than on equity foreign bias. We also show that the level of financial development is more important for attracting foreign bond investors than foreign equity investors; and country and corporate governance practices matter more for international equity portfolios than for international bond portfolios. Besides variables being significantly more, less or incompatibly important for bond versus equity home and foreign bias, we also find variables exclusively significant for bonds. Above all this paper points out the distinct nature of bond home and foreign bias versus equities and, therefore, stimulates further research on bond home and foreign bias despite the large amount of existing literature on equity home bias.
\end{abstract}




\section{INTRODUCTION}

The preference of investors for domestic assets over international ones is commonly known as home bias. Due to the limited availability of quality data on international bond holdings, most research has been carried out on equity holdings (see Lewis, 1999; Karolyi \& Stulz, 2003; Sercu \& Vanpée, 2012). Recently international bond holdings data has become more readily available at higher quality levels through, for example, the Coordinated Portfolio Investment Survey (CPIS) conducted annually by the IMF since 2001 .

Besides the recent improvements in data availability, studying bond home bias can be motivated by several other factors. To our knowledge, there is no study that compares home bias in equities with bonds on one large scale dataset. There is a lack of exploratory studies on the magnitude of home bias in equities versus bonds (see Section 2). An exploratory study is interesting not only for the empirical results but also for the methodological approach. There is an issue of comparability of home bias measures of equities and bonds. Can the usual measures be compared when applied to equities and bonds, or do we need to rescale? And how?

We find a large dispersion of home bias between equities and bonds across countries. For some countries the difference between equity and bond home bias is small, for others it is largely positive or negative. Given this large dispersion and the lack of any obvious pattern, an explanatory study is also justified. We tried to explain bond home bias using explanatory variables commonly used to explain equity home bias, and found much lower R-squares. ${ }^{1}$ This motivates further research on explanatory variables specifically important for bond home bias. The search for these variables is interesting not only for economic interpretation or theory, but also methodologically. As we show, one needs to estimate the equity and bond

\footnotetext{
${ }^{1}$ Using the commonly known variables that explain the equity home bias in a bond home bias regression, we find an adjusted R-squared of $61 \%$. Adding debt-specific variables to the model, the explanatory power increases to $72.5 \%$.
} 
regressions simultaneously in order to make correct statements about the asset-specific drivers.

The equity home bias puzzle is still something not completely understood. Studying the home bias in bonds may generate new and fresh ideas from which the understanding of equity home bias may benefit. For example, by studying equity and bond home bias simultaneously on one large dataset both in terms of countries and time period, it is possible to distinguish asset-invariant home bias drivers from asset-specific drivers; and countryinvariant drivers from country-specific drivers; and time-invariant from time-specific drivers. This distinction may generate new insights into the general home bias debate.

Identifying the differences in the countries' bond and equity home bias is important because the countries' representative agents can miss diversification opportunities in equities or bonds only, or in both, or even compensate equity under diversification through its international bond holdings. This is the question of whether equities and bonds are complements or substitutes for international diversification (e.g. Hahm \& Shin, 2009).

Lastly, countries that cannot attract foreigners to invest in their local currency bonds run the risk of currency mismatches that can result in painful crises. Burger \& Warnock (2007), for example, find that U.S. investors fail to diversify their bond portfolios fully and avoid, especially, the most volatile bond markets representing mostly emerging economies. Understanding this underinvestment in emerging market bonds can help policy making decisions with respect to emerging markets.

The aim of this paper is not to answer all the research questions mentioned earlier. Instead this paper aims to stimulate further research on an asset class that is too interesting to ignore in the home bias debate. This is established by exploring the difference between the bond- and equity home and foreign bias based on one large scale dataset including developed 
(OECD) and emerging markets (EMs). ${ }^{2}$ Before we turn to the more formal discussion, Figure 1 illustrates that home bias is more severe in EMs than in OECD countries. Interestingly, the OECD countries are more biased towards domestic bonds than towards domestic equity, especially since 2006, when bond home bias increased considerably after a five year steady decline. For the EMs, the bias in bonds is, on average, smaller than in equities, but the difference is minimal. Both equity and bond home bias hardly changed over the ten year sample period.

[Insert Figure 1 about here]

We see two explanations for the diversion of bond home bias from equity home bias in OECD countries. In the years before and during the global financial crisis, many OECD countries were running increasing current account deficits and were engaged in high levels of public spending. To cover these deficits, public debt was issued, usually under the form of government bonds. A large portion of newly issued government bonds is typically held by domestic investors. Banks hold government debt to cover reserve requirements and most pension funds are required to hold a certain percentage of long term domestic bonds for duration matching. So a first explanation for the increased bond home bias could be mainly supply-side driven by increasing levels of public debt. An alternative explanation for the increased bond home bias is demand driven. If (domestic) bond returns outperform foreign bonds and/or stocks, investors will divert to investments in home country bonds. During the financial crisis, a flight-to-quality from equity to domestic bonds can also lead to a similar investment pattern. However, this presumption fails to explain the continuing decline in equity home bias, which has become even steeper during the crisis years, indicating that investors did not observe foreign equity to be less attractive than domestic stocks. Still, since

\footnotetext{
${ }^{2}$ A list of the OECD countries and the EMs used in our sample is provided in the Appendix.
} 
the current global crisis has focused on credit and later public debt levels, a sudden aversion for foreign bonds is not unlikely.

To get a better picture of the relationship between home bias and public debt levels, we take a closer look at two countries: Greece, that had an increasing government debt over the past ten years and Russia, where public debt levels followed a decreasing trend. For both countries, we observe that the bond home bias follows the trend in public debt levels. A size effect can be excluded, because our home bias measures are corrected for size (see Section 3). The equity home bias seems to be unaffected by the size of the government debt. This indicates that, at least for Greece, the increase in bond home bias is driven by the sharp increase in government debt from 2005 to 2010.

\section{[Insert Figure 2 about here]}

The remainder of this paper is structured as follows. In Section 2 we review the restricted literature on bond home bias. Section 3 explains the home- and foreign bias measures and the regression equations. Section 4 describes the data, taking special care of the explanatory variables. Section 5 discusses the regression results and Section 6 concludes.

\section{LITERATURE REVIEW}

Due to the limited availability of quality data on international bond holdings, studies on home bias in bond markets are scarce.

Levy \& Lerman (1988) document the potential benefits of international bond diversification. They show that U.S. investors specializing in bonds could have improved their portfolio performance over the $1960-80$ period by 3 to 5 per cent a year by diversifying internationally rather than restricting their investments to domestic bonds. They conclude that it is the low correlations between the bond markets in various countries, compared with the 
correlations across the international stock markets, that account for the potential gains from international diversification in bonds.

Lane (2006) uses an empirical method borrowed from the traditional gravity models of the international goods trade and examines the bilateral composition of international bond portfolios for the euro area and the individual EMU member countries. He finds evidence for euro area bias by observing that EMU member countries disproportionately invest in one another relative to other country pairs.

Fidora, Fratzscher, \& Thimann (2007) compare the home bias in equities and bonds, but on a smaller data set than ours. They find that bond home bias is, on average, more pronounced than equity home bias and, according to their benchmark model, real exchange rate volatility can explain around $20 \%$ of the cross-country variation in equity and bond home biases. This is because the contribution of real exchange rate volatility to the real volatility of an asset is higher for foreign assets with lower returns. Compared to Fidora et al., we include more explanatory variables in our study, and we take into account the issue of comparability and rescaling. Also we apply a formal statistical test to check for the difference in drivers for equity and bond home bias, an approach which is necessary in order to reach correct conclusions.

Burger \& Warnock (2007) analyse the ability of countries to attract U.S. investors to their local bond markets. They find that U.S. investors participate very little in local currency bond markets overall, and especially in emerging markets. Based on a three-moment CAPM they find that U.S. investors avoid local currency bonds that have returns with historically high variance and negative skewness. Decomposing these risks, they find that U.S. investors are avoiding diversifiable idiosyncratic risk, an indication of the home bias in portfolios.

Schoenmaker \& Bosch (2008) show that both the equity and the bond home bias amongst Eurozone countries have decreased significantly since the introduction of the euro. 
The decline in the bond home bias is more pronounced, indicating the importance of exchange rate risk. However, EMU countries still show severe home bias in both equities and bond portfolios, and the differences in home bias between the EMU countries is larger for bonds than for stocks.

Hahm \& Shin (2009) employ a variant of gravity models and find strong evidence for the presence of complementarities among debts and portfolio equity holdings. They partially explain this by common factors such as economy size, state of economic development, and information cost proxies (such as distance).

Coeurdacier \& Martin (2009) also analyse the impact of a currency union on the trade in bond, equity and banking assets. Using a gravity model, they document that the introduction of the euro significantly reduces transaction costs inside the euro zone making it cheaper for all countries to buy euro zone assets. They also find a diversion effect which leads euro zone countries to purchase fewer non euro assets.

De Santis \& Gérard (2009) look at the determinants of bilateral changes in portfolio country weights in both equity securities and fixed income for a panel of thirty countries. They find that the strongest drivers are the marginal diversification benefits arising from the pure asset component (i.e. non-linear fully hedged diversification benefits) and the initial degree of underweight. This evidence suggests that global portfolio reallocations over the asset boom and bust period were determined by optimal diversification considerations. They also find that due to economic and monetary union (EMU) the weight assigned by euro area investors to investment in euro area countries increased significantly in equity and fixed income portfolios.

De Santis (2010) investigates whether portfolio flows and, therefore, the global reallocation of portfolio capital across twenty-three developed countries and seven emerging market economies are functions of the optimal weights at the beginning of the period, as 
suggested by the International CAPM (Solnik, 1974; Sercu, 1980). He finds that portfolio asset flows are influenced positively by the relative size of the recipient countries' financial markets, and that the predictions of the International CAPM are only partially met, in view of the fact that the estimated coefficient on the benchmarks is less than unity: 0.4 for the equity portfolio and 0.2 for the bond portfolio i.e. global equity markets might be more integrated than global bond markets. Moreover, over the turbulent 1998-2001 period characterized by an equity bubble and the subsequent burst, they find evidence that investors preferred portfolio assets of countries where the central bank gave relative priority to money. As for EMU, once controlling for diversification benefits and the elimination of the exchange rate risk, they show that cross-border portfolio flows among euro-area countries have increased due to the catalyst effect of EMU. Countries' shares in the world market portfolio, home bias, initial degree of misallocation across countries, past returns, diversification benefits, and EMU can explain 35-40 percent of the total variation in equity and bond asset flows.

\section{METHODOLOGY}

\subsection{Home bias}

Traditionally, a country's equity home bias is defined as the difference between the proportion of the total equity portfolio invested in home equity and the relative weight of the domestic stock market in the global equity market capitalization (Sercu \& Vanpée, 2012; Cooper \& Kaplanis, 1994; Brealey, Cooper, \& Kaplanis, 1999):

$$
H B_{i}^{e q}=\frac{E Q_{i, i}}{T E Q_{i}}-\frac{M E Q_{i}}{W E Q^{\prime}}
$$

where $E Q_{i, i}$ represents the domestic equity holdings of investors from country $i, T E Q_{i}$ is the total equity portfolio held by investors from country $i, M E Q_{i}$ is the equity market capitalization of country $i$ and $W E Q$ is the total market capitalization of equities worldwide. Similarly, bond home bias can be defined as: 


$$
H B_{i}^{b d}=\frac{B D_{i, i}}{T B D_{i}}-\frac{M B D_{i}}{W B D}
$$

where $B D_{i, i}$ represents the domestic bond holdings of country $i, T B D_{i}$ denotes the total bond portfolio held by investors of country $i, M B D_{i}$ is country $i$ 's bond market capitalization and $W B D$ is the world bond market capitalization. The home bias measures range from 1 (fully home biased) to $-M / W$ (all assets held abroad). Bekaert \& Wang (2009) indicate that there is a size effect in the traditional home bias measure: for large markets, home bias will be relatively small by definition. For example, if the United States, with a total market capitalization of 40 percent of the global market cap, invests 90 percent domestically, the country's home bias equals 50 percent. If Belgium with a total market cap of 0.5 percent invests 90 percent at home, Belgium's home bias is 85 percent. The question is thus, whether it is reasonable to claim that the Belgian situation is 1.7 times worse than the underdiversification in the U.S.. To solve the size bias, Bekaert \& Wang (2009) propose to scale the traditional home bias measure by the maximum home bias:

$$
\overline{H B}_{i}=\frac{H B_{i}}{\left(1-\frac{M_{i}}{W}\right)}
$$

Table 1 shows the traditional equity and bond home bias and the scaled version for a sample of 42 countries at the end of 2010. Scaling significantly alters the home bias for large countries only. The correlation between the unscaled and the scaled home bias measure is 98 percent for equities and 96 percent for bonds. Both the unscaled and scaled measures show the lowest equity home bias in the Netherlands (respectively 33.5 and 34 percent) and the highest equity home bias in Egypt (99.7 and 99.9 percent). Bond home bias is lowest in Hong Kong (31.2 and 31.3 percent) and the highest in Egypt (99.7 percent according to the unscaled measure) or India (100 percent according to the scaled version). In general, EMs show more home bias than industrialized countries.

[Insert Table 1 about here] 


\subsection{Foreign bias}

Following Chan, Covrig, \& Ng (2005) and Bekaert and Wang (2009), we distinguish home bias (overinvestment in the home country) from foreign asset bias (underinvestment abroad). Unscaled, the underinvestment equity bias of country $i$ in country $j$, is the difference between the optimal equity holdings of country $j$, and the actual holdings of country $i$ in country $j$ 's stocks:

$$
F B_{i, j}=\frac{M E Q_{j}}{W E Q}-\frac{E Q_{i, j}}{T E Q_{i}}
$$

The foreign bias for bond portfolios is calculated in a similar way. Bekaert and Wang (2009) propose a measure for foreign asset bias that reflects the relative attractiveness of the foreign country by looking at the market capitalizations that are freely available to global investors. Or, stated differently, the foreign bias measure controls for all existing home biased asset allocations. We use the Bekaert and Wang foreign bias measure to analyze underinvestment from country $i$ in country $j$ :

$$
F B_{i, j}^{e q}=\frac{M E Q_{j}-E Q_{j, j}}{W E Q-M E Q_{i}-\sum_{k \neq j} E Q_{k, k}}-\frac{E Q_{i, j}}{T E Q_{i}-E Q_{i, i}}
$$

This foreign bias measure is normalized such that the values lie between -1 and 1 :

$$
F B_{i, j}^{e q}=\left\{\begin{array}{l}
\frac{w_{i, j}^{e q}-a_{i, i}^{e q}}{w_{i, j}^{e q}} \text { when } a_{i, j}^{e q} \leq w_{i, j}^{e q} \quad \text { (underinvestment) } \\
-\left(\frac{a_{i, j}^{e q}-w_{i, j}^{e q}}{1-w_{i, j}^{e q}}\right) \text { when } a_{i, j}^{e q}>w_{i, j}^{e q} \quad \text { (overinvestment) }
\end{array}\right.
$$

where $w_{i, j}^{e q}$ represents the benchmark weight and is equal to the first part of equation (5) and $a_{i, j}^{e q}$ is the actual weight of investor $i$ 's investment in stocks of country $j$. In the same way, the normalized foreign bias measure for the bond markets is defined as:

$$
F B_{i, j}^{b d}=\left\{\begin{array}{l}
\frac{w_{i, j}^{b d}-a_{i, i}^{b d}}{w_{i, j}^{b d}} \text { when } \quad a_{i, j}^{b d} \leq w_{i, j}^{b d} \quad \text { (underinvestment) } \\
-\left(\frac{a_{i, j}^{b d}-w_{i, j}^{b d}}{1-w_{i, j}^{b d}}\right) \text { when } a_{i, j}^{b d}>w_{i, j}^{b d} \quad \text { (overinvestment) }
\end{array}\right.
$$




\subsection{Estimation}

We estimate the drivers of equity and bond home and foreign bias simultaneously as a system of equations. By applying a Wald test, we can determine whether an explanatory variable $X_{i}$ has a significantly different impact on international equity and bond holdings. For the home bias equations, we distinguish between three different types of explanatory variables: interaction variables between country $i$ and the world $\left(X_{i, w, t}\right)$, country-dependent variables $\left(X_{i, t}\right)$ and equity market (bond market) specific variables of country $i\left(X_{i, t}^{e q}\right.$ and $\left.X_{i, t}^{b d}\right)$ :

$$
\left\{\begin{array}{l}
H B_{i, t}^{e q}=\alpha_{i, t}^{e q}+\beta^{e q} X_{i, w, t}+\delta^{e q} X_{i, t}+\gamma^{e q} X_{i, t}^{e q}+\varepsilon_{i, t}^{e q} \\
H B_{i, t}^{b d}=\alpha_{i, t}^{b d}+\beta^{b d} X_{i, w, t}+\delta^{b d} X_{i, t}+\gamma^{b d} X_{i, t}^{b d}+\varepsilon_{i, t}^{b d}
\end{array}\right.
$$

A Wald test then tests whether:

$$
\begin{aligned}
& \beta^{e q}=\beta^{b d} \\
& \delta^{e q}=\delta^{b d} \\
& \gamma^{e q}=\gamma^{b d}
\end{aligned}
$$

For the foreign bias equations, the interaction variables between the home country and the world are replaced by interaction variables between home and host country $\left(X_{i, j, t}\right)$ :

$$
\left\{\begin{array}{c}
F B_{i, j, t}^{e q}=\alpha_{i, t}^{e q}+\beta^{e q} X_{i, j, t}+\delta^{e q} X_{i, t}+\lambda^{e q} X_{j, t}+\gamma^{e q} X_{i, t}^{e q}+\mu^{e q} X_{j, t}^{e q}+\theta^{e q} X_{i, j, t}^{e q}+\varepsilon_{i, t}^{e q} \\
F B_{i, j, t}^{b d}=\alpha_{i, t}^{b d}+\beta^{b d} X_{i, j, t}+\delta^{b d} X_{i, t}+\lambda^{b d} X_{j, t}+\gamma^{b d} X_{i, t}^{b d}+\mu^{b d} X_{j, t}^{b d}+\theta^{e q} X_{i, j, t}^{b d}+\varepsilon_{i, t}^{b d}
\end{array}\right.
$$

We also add time dummies to the regressions, to account for a potential time trend in the data. Equations (8) and (9) are then estimated by Seemingly Unrelated Regression (SUR).

\section{DATA}

\subsection{Portfolio holdings}

Data on international portfolio holdings are retrieved from the Coordinated Portfolio Investment Survey (CPIS), conducted annually by the IMF since 2001. Our sample contains data on 42 countries, both developed and emerging over a period of ten years (2001-2010). The CPIS dataset suffers from two shortcomings. First, a number of countries, for example China and the Arab countries, did not participate in the CPIS resulting in an incomplete 
country coverage. Second, the CPIS does not take effects of third-party holdings or round tripping into account. This creates misleading results for countries such as Luxembourg, Ireland and some smaller off-shore financial centres. To partly overcome this last shortcoming, we reallocate investments in off-shore financial centres over the sample countries in proportion to the foreign investments of these centres. ${ }^{3}$ Equity market capitalizations are from the World Federation of Exchanges and bond market capitalizations are from the Bank of International Settlements (BIS).

To construct the international bond portfolios, we look at long term bonds only. Short term bond holdings (maturities smaller than one year) are typically money market instruments and treasury bills that are held for hedging purposes. Including these instruments in our bond portfolios could lead to biased results.

\subsection{Explanatory variables}

To explain the differences between equity and bond home bias and foreign bias, we use a set of variables that have been proven to be correlated with international investment decisions (amongst others Bekaert \& Wang, 2009; Sercu \& Vanpée, 2008; Chan, Covrig, \& Ng, 2005; Fidora et al., 2007, Ahearne, Griever, \& Warnock, 2004; and Burger \& Warnock, 2003). As most of these variables are specifically used for explaining international equity holdings, we add bond-specific variables (credit ratings, debt levels and debt growth ratios) to our analysis to gain further insight into the difference between bond and equity holdings.

\subsubsection{Information asymmetries and proximity}

A popular explanation for home bias is that investors have less information about foreign assets than about domestic ones and therefore prefer to invest in what they are familiar with. To proxy for information asymmetries and familiarity we include four variables: Distance,

\footnotetext{
${ }^{3}$ Sercu and Vanpée (2008) show that alternative allocation methods for the investments from and into financial off-shore centres do not meaningfully affect estimation results.
} 
Language, English and Trade. Distance is calculated as the log of the physical distance between the home and host country. The common language variable is a dummy that takes on the value of one if two countries share the same language and zero otherwise. English is a dummy variable that takes the value of one if the host country has English as its official language. The trade variable is constructed to measure the intensity of bilateral trade between the host and home country and is calculated as the sum of bilateral imports and exports divided by the GDP of the home country. Distance is expected to come up with a positive sign in the home and foreign bias regressions, while language, English and trade should be negatively related to home and foreign asset bias.

\subsubsection{Market liberalization}

It has been well documented that barriers to international capital flows can still hamper international asset allocation, especially in emerging markets (Edison \& Warnock, 2003). We apply the Financial Reform Index (FRI) developed by Abiad, Detragiache, \& Tressel (2008) to measure financial liberalization. This index is a non-binary measure which captures various stages of liberalization on a 1-21 score. Scores are given on seven dimensions of financial sector policy: credit controls and reserve requirements, interest rate controls, entry barriers, state ownership in the banking sector, capital account restrictions, prudential regulations and supervision of the banking sector and securities market policy. As a higher FRI score indicates a higher stage of financial market liberalization, we expect this measure to correlate negatively with both home and foreign asset bias.

\section{$\underline{4.2 .3 \text { Financial market development }}$}

Investors will be more inclined to invest abroad if the foreign market is well developed. We apply two variables to proxy for financial market development, notably market capitalization relative to GDP $(M C / G D P)$ and domestic credit provided by the banking sector as a percentage of GDP $(C R E D I T / G D P)$. Equity market capitalizations, GDP and credit data are 
retrieved from the World Bank. Bond market capitalizations are retrieved from the Bank of International Settlements. Market size is a commonly used indicator for market development (amongst others Levine \& Zervos, 1998; Burger \& Warnock, 2003; Bekaert \& Wang, 2009) and bond market capitalization is also a reasonable although imperfect proxy for bond market liquidity (McCauley \& Remolona, 2000). We expect both measures for financial development to correlate negatively with home and foreign asset bias. Burger \& Warnock (2007) indicate that countries that issue international bonds are better able to attract foreign investors than countries that issue local bonds. Therefore we include the variable Intl_debt that measures the proportion of international bonds to total bond market capitalization. As countries with more international debt are assumed to show a lower home and foreign bias, we expect the coefficient estimate for this variable to be negative.

\subsubsection{Economic health \& stability}

We include three variables to proxy for the economic health and stability in a country, notably GDP, GDP growth and the misery index (Misery). GDP serves as an indicator for market size and is measured as the country's GDP relative to total world GDP. GDP growth is measured as the average growth rate over the three preceding years. The misery index of a country is the sum of its inflation rate and its unemployment rate, and measures the degree of a country's macro-economic distress. Both unemployment rates and inflation rates are retrieved from the World Bank. Home bias can be both positively and negatively related to GDP and GDP growth. A country with a large GDP typically has a lot of diversification opportunities at home, such that international diversification becomes less important. In this case, the coefficient estimate for GDP will be positive. On the other hand, large countries can be perceived to be more attractive and accessible, which will attract foreign investors and lead to lower home bias and foreign bias figures. As far as GDP growth is concerned: on the one hand, strong growing countries are usually attractive for investors, but on the other hand, fast 
growing economies are typically emerging markets, which can have other features like high uncertainty that scare off international investors. A high score on the misery index adds to uncertainty and macro-economic distress, so the misery index is expected to correlate positively with home and foreign asset bias.

To test whether home and foreign bias differ for OECD countries and emerging markets, we include a dummy variable that takes the value of one if the country is an OECD member, and zero otherwise. Based on Figure 1, we expect the coefficient estimate to be negative, indicating a lower bias for OECD countries. A potential explanation for the exceeding bond home bias is a higher level of public debt. To test this hypothesis, we include three variables: government debt relative to GDP (Debt), public debt growth measured as the mean growth rate over the three preceding years (Debt_growth) and the S\&P country credit rating (Rating). We transform Standard and Poor's country ratings into a numeric score ranging from one (AAA) to $21(\mathrm{C})$. We don't expect that these debt-related variables will impact equity home bias directly, but an indirect effect might come up as low ratings and high debt levels are correlated with weak policies. In the bond home and foreign bias regressions, we expect the coefficient estimates for debt, debt-growth and rating to be positively related to home and foreign bias.

\section{$\underline{4.2 .5 \text { Governance }}$}

Kho, Stulz, \& Warnock (2009), Doidge, Karolyi, \& Stulz (2007) and Gelos \& Wei (2005) show that foreign portfolio investors exhibit an underinvestment bias towards countries with poor governance, partly because of the limited supply of freely available shares due to the presence of controlling shareholders, and partly because of the poor level of protection of minority shareholders. Following Gelos \& Wei (2005) and Sercu \& Vanpée (2008), we distinguish between country level governance and corporate governance by allowing for two governance related variables. The government effectiveness indicator (Goveff) is a measure of 
country level governance and captures the effects of the quality of government institutions in general. The government effectiveness indicator is developed by Kaufmann, Kraay, \& Mastruzzi (2009) and can be retrieved from the World Bank. As an indicator of corporate governance we use the corporate board efficacy indicator (Corp_board), obtained from the Global Competitiveness Report.

\subsubsection{Diversification opportunities \& performance}

If investors aim to exploit diversification benefits, one would expect them to prefer assets that are only weakly correlated with their domestic portfolio. Therefore, we include the 5-year equity (bond) return correlation between the home and host country in the equity (bond) home and foreign bias regressions. Some authors show that investors display return chasing behaviour by investing more in foreign markets that performed well (Bohn \& Tesar, 1996; Chan et al., 2005; Ahearne et al., 2004). We also correct for risk by introducing the Sharpe ratio of the sample year and one-year lagged Sharpe ratio of the host country as explanatory variable (Shape and Sharpe_lag). Finally, we expect that investors prefer positive skewness in returns, thus we add the standardized skewness (Skew) for the return of the host-country. The skewness variable is expected to have a positive effect on home bias and a negative effect on foreign bias. Equity returns are MSCI country indices and bond returns are Barclays Multiverse indices. ${ }^{4}$ For the bond markets that don't have a Multiverse Index, we use JP Morgan country indices. All return data are retrieved from Thomson Reuters Datastream.

\section{$\underline{4.2 .7 \text { Foreign exchange rate risk }}$}

Hedging foreign exchange rate risk is another popular explanation for international underinvestment (Fidora et al., 2007). Baele, Pungulescu, \& Ter Horst (2007) find that home bias has been decreasing faster for countries that are part of the European Monetary Union

\footnotetext{
${ }^{4}$ The Barclays Multiverse Index includes all investment-grade and high-yield securities of a country, regardless of currency.
} 
than for other countries. To account for foreign exchange rate risk we include three variables: a dummy variable that takes the value of one if the home and host country are a member of the Euro Area and zero otherwise (Euro), the real exchange rate volatility between the home and host country measured by monthly data over a period of ten years (RER_vol) and the change in the real exchange rate of the home and host country's currencies over the past year $(R E R)$. To be consistent with the literature, the euro variable should be negatively correlated with the home and foreign bias and the real exchange rate variables are expected to come up with a positive sign. Fidora et al. (2007) show that real exchange rate volatility is more important for bond home bias than for equity home bias, and therefore we expect the Waldtest for equality of the coefficient estimates in the equity and bond equations to be rejected.

\section{RESULTS}

\subsection{Home bias regressions}

Table 2 shows the estimation results for the home bias regressions as specified in equation (8), for the total sample of 42 countries over the period 2001 to 2010. For India and Mexico, home bias data start in 2003, due to missing data in the CPIS dataset. Time dummies are added to the regressions to account for a potential time trend. However, for both the equityand bond home bias, none of the time dummies is significant. For reasons of visibility, they are excluded from Table 2. The table shows the coefficient estimates and their corresponding p-values for the drivers of equity home bias and bond home bias, and the last two columns show the Wald tests for equality of the corresponding equity and bond home bias coefficient. As the main focus of this paper is to point out the difference between equity and bond home bias — not to explain home bias as such — the discussion of the results will be focused on the Wald tests.

[Insert Table 2 about here] 
The results in Table 2 indicate that the level of financial development (Findev) is significantly more influential for bond home bias than for equity home bias: both equity and bond home bias are higher in countries with less developed financial markets, but the impact is more pronounced for bonds. As could be expected, the proportion of international bonds in the total bond market capitalization (Intl_debt) has a larger reducing effect on bond home bias than on equity home bias. Still, as the proportion of international debt also seems to reduce the equity home bias, we assume that this variable correlates positively with the international orientation of a country in general. The level and the growth of a country's government debt (Debt, Debt growth) are asset-specific drivers. The equity home bias is not influenced by these variables, whereas the bond home bias is significantly positively influenced by the level of public debt and the growth in public debt over the recent years. This result is in line with the hypothesis of a supply-side effect in bond home bias (see supra: introduction). Having a poor credit rating (Rating) will impact bond portfolios more than equity portfolios. As sovereign credit ratings mainly affect (sovereign) bond returns, and only to a lesser extent equity returns, this result is quite logical. As far as the other variables for economic health and stability are concerned, we find that the size of the economy (GDP) has a negative effect on bond home bias, but no effect on equity home bias. The coefficients of the growth rate of the economy (GDP growth) suggest that faster growing countries exhibit a higher equity home bias, while the effect on bond home bias is only marginally significant. The coefficient estimate for the $O E C D$ dummy is significantly negative for both types of home bias i.e. home bias is lower in OECD countries than in Ems which is in line with Figure 1.

With respect to the governance variables, we notice that both country level (Goveff) and corporate governance practices (Corp_board) seem to influence equity home bias only. But the Wald test indicates that only corporate governance has a different impact on equity and bond home bias. A potential explanation is that corporate governance, measured here as 
the efficiency of corporate boards, is especially relevant for shareholders, and probably less important for bond holders.

We find no convincing evidence for the demand driven explanation of bond home bias i.e. the return chasing behaviour and flight-to-capital. The one-year lagged Sharpe ratio (Sharpe_lag) and the Sharpe ratio (Sharpe) are statistically insignificant in both the equity and bond home bias regressions. Similarly, the coefficient estimate of return correlation (Correl) is insignificant for both asset biases. For skewness (Skew), we find that it only affects equity home bias, indicating that countries with positive skewness in their equity returns are more home biased.

In contrast to Fidora et al. (2007), our results do not indicate that real exchange rate risk is more important for bonds than for equities. Although we do find that the positive coefficient estimate for real exchange rate volatility (RER_vol) is larger for bond home bias than for equity home bias, the Wald test cannot confirm that the coefficient estimates are significantly different. The effect of a common euro currency (Euro) does impact equity portfolios in a different way from bond portfolios: home bias is lower in Eurozone countries, both for equities and for bonds, but the impact on bond home bias is more pronounced.

\subsection{Foreign bias regressions}

We now turn to the discussion of the estimation results of the foreign bias regressions as specified in equation (10), which are presented in Table 3. The table contains the coefficient estimates, their corresponding p-values and the Wald tests for the full sample of 42 countries over the period 2001-2010. As for the home bias regressions, time dummies were added to the regression specification, but as all coefficients were insignificant, we don't show them in the table. As the year-by-year dummies are insignificant, we can't confirm a specific time trend in the foreign equity or bond bias.

[Insert Table 3 about here] 
The information-related variables show some differences between equity and bond foreign bias. Proximity (Distance) seems to matter more for international equity investments than for bonds, whereas sharing a strong trade relationship (Trade) impacts international bond portfolios more than equities. Interestingly — but puzzlingly — countries that have English (English) as their official language attract more foreign equity investment, but less foreign bond investments.

As with home bias, the level of financial market development (Findev_host; Credit_host; Intl_debt_host) is more influential for foreign bond bias than for foreign equity bias. A well-developed bond market will attract more foreign investments, ceteris paribus, than a well-developed equity market. A possible explanation for this finding is that the majority of the countries in our sample (OECD and EMs) have well-developed equity markets in comparison to bond markets. Eichengreen \& Luengnaruemitchai (2004) and Eichengreen, Borensztein, \& Panizza (2006), for example, document the relative underdevelopment of Asian and Latin-American debt markets compared to their equity markets and compared to other countries. This leads to more cross-country variation in the financial development of bond markets than of equity markets.

A higher level of public debt in the host country (Debt_host) or in the home country (Debt_home) increases the foreign bias. As expected, the impact is larger for bond markets than for equity markets. Thus, if a country has a high level of government debt at home, it will invest less abroad. This is because citizens compose their bond portfolios mainly of domestic debt. Additionally, the country will attract fewer foreign investors who are put off by the high level of government debt and the worsened creditworthiness associated with the increased debt level. A similar conclusion can be drawn from the results for the growth in government debt (Debt_host_growth; Debt_home_growth). The aversion to credit risk is also reflected in the coefficient estimate of the credit rating (Rating_host) variable: countries with a lower 
credit rating attract fewer foreign bond investors. Interestingly, this result does not hold for equities: we find that, on average, low sovereign credit ratings come with lower foreign equity bias.

We find that $O E C D$ countries exhibit a lower foreign bias than EMs (OECD_home) both for equities and bonds. But OECD countries attract fewer foreign bond investments than EMs (OECD_host). The host country development (GDP_host) seems to matter more for equities than for bonds.

Our conclusions with respect to the impact of corporate governance (Corp_board) and political risk (Goveff) on foreign bias are similar to those for home bias: good governance practices, both on the country and the corporate level, matter for equity investments only. Apparently, investors look first to other characteristics like the bond's credit rating or a country's leverage before caring about governance issues when considering foreign bond investments.

Diversification benefits are not exploited in both equities and bonds. On the contrary, the foreign bias is lower between countries that have higher correlated equity and bond market returns (Correl). This effect is more pronounced for equities than for bonds. Investors do not seem to chase positive skewness in returns, (Skew) nor do they chase past equity or bond risk-adjusted returns (Sharpe_lag).

In contrast to what we found for home bias, real exchange rate risk does matter considerably in determining bond and equity foreign bias. In line with Fidora et al. (2007), our results indicate that the impact of real exchange rate volatility is more pronounced for bonds than for equities. Having a common euro currency (Euro) has a similar decreasing effect on foreign underinvestment in bonds and equities.

\subsection{Robustness check}


We test the robustness of our results when matched against the modified Bekaert and Wang (2009) home and foreign bias measures, by running similar regressions with the traditional home and foreign bias measures as dependent variables. Thus, we calculate the equity and bond home bias as specified in equations (1) and (2) and the foreign bias measures are calculated as specified in equation (4). Tables A2 and A3 in the Appendix show the results.

The results for the home bias regressions with the traditional home bias measure as left-hand side variable are very similar to our results as presented in Table 2 (Table A2). This isn't surprising as the correlation between the scaled and unscaled home bias measures is very high (cfr. supra). The general fit of the model is slightly higher when explaining the traditional home bias: adjusted $\mathrm{R}^{2}$ for the equity home bias increases from 77 percent to 79 percent and for bond home bias from 73 percent to 74 percent. This slightly better fit is due to the size-effect in the traditional home bias measure. Size is picked up by the GDP variable that is now significant in explaining both equity and bond home bias.

Table A3 shows the estimation results for the foreign bias regressions, with the traditional foreign bias measure as dependent variable. If we compare the results from Table A3 with the ones from Table 3, we note that the overall fit of the model improves signifcantly when the traditional home bias measure is used as left-hand side variable. For equities, the adjusted $\mathrm{R}^{2}$ increases from 39 to 91 percent, while for bonds the increase is even more spectacular: from 22 to 95 percent. Although the fit seems better, our results regarding the difference in equity and bond foreign bias remain valid. First, countries with a high level of government debt and an accelaterating debt level attract less foreign investment in their bond assets, while foreign equity investment is not affected in this way. Second, the level of financial development matters more for bond markets than for equity markets. Third, the impact of governance, both on the country and on the firm level matters more for attracting 
foreign equity investors than bond investors; and fourth, real exchange rate volatility has a bigger impact on foreign bond holdings than on foreign equity holdings.

The difference between the traditional measure and the Bekeart and Wang foreign bias measure is revealed in the coefficient estimates for the GDP of the home country and the host country. Using the scaled foreign bias measure, estimation results indicated that the foreign bias in both bond and equities is lower if the GDP of the host and the home country is high (Table 3). The traditional foreign bias measure leads to the opposite conclusion: foreign bias will be higher for host and home countries with a high GDP (Table A3). This means that the Bekeart and Wang measure succeeds in its aim of correcting for size and indicates that ignoring the size-effect in home and foreign bias can lead to contradictory conclusions.

\section{CONCLUSION}

The existing literature on bond home bias is quite restricted because of the historically limited availability of quality data on international bond holdings. This is, however, not an issue any more as the Coordinated Portfolio Investment Survey (CPIS) has been conducted annually by the IMF since 2001. Nevertheless the level of research interest in bond home bias is low, something that is undeserved as we argue. Besides the recent availability of data we see many other reasons for further investigating the observed preference towards domestic bonds, such as: the lack of exploratory studies on the magnitude of home bias in bonds versus equities, the issue of comparability of bond and equity home bias measures, the large dispersion of home bias between equities and bonds across countries, the low R-squares when explaining bond home bias using explanatory variables commonly used to explain equity home bias, the issue of simultaneous estimation of bond and equity home bias, the potential spill-over effects of bond home bias research insights in terms of new insights into equity home bias, the issue of bonds as complements to or substitutes for international diversification, and the economic link 
between the ability to attract foreign investors to local currency bonds and the risk of currency mismatch, possibly resulting in economic crises.

We point out four main differences in equity and bond home and foreign bias. First, we set the stage by tentatively — and later on, more formally — linking the diversion of bond and equity home bias in OECD countries (since 2006) to the increasing government budget deficits and engagement in high levels of public spending covered by increasing public debt issues under the form of government bonds i.e. the supply-driven argument. Second, unlike Fidora et al. (2007) we do not find that exchange rate volatility matters more for bonds than for equities in explaining home bias, but we do find this discrepancy in explaining foreign bias. Third, we show that governance issues, both on the country and on the corporate level, matter more for international equity portfolios than for intenational bond portfolios. Fourth, we show that improving the level of financial development is more important for attracting international bond investments than international equity investments. This is probably due to the fact that equity markets are, in general, already well developed in our sample countries, while there is more room for improvement in the bond markets. In general the motivation, the results and the tentative explanations in this paper should stimulate further research on an asset class that is too interesting and too distinct to ignore with respect to home and foreign bias.

\section{REFERENCES}

Abiad, A., Detragiache, E., \& Tressel, T. (2010). A New Database of Financial Reforms. IMF Staff Papers, 57, 281-302.

Ahearne, A. G., Griever, W. L., \& Warnock, F. E. (2004). Information costs and home bias: an analysis of US holdings of foreign equities. Journal of International Economics, 62(2), 313-336. 
Baele, L., Pungulescu, C., \& Horst, J. T. (2007). Model uncertainty, financial market integration and the home bias puzzle. Journal of International Money and Finance, 26(4), 606-630.

Bekaert, G., \& Wang, X. (2009). Home bias revisited. SSRN Working Paper Series.

Bohn, H., \& Tesar, L. L. (1996). U.S. Equity Investment in Foreign Markets: Portfolio Rebalancing or Return Chasing? The American Economic Review, 86(2), 77-81.

Brealey, R. A., Cooper, I., \& Kaplanis, E. (1999). What is the International Dimension of International Finance ? European Finance Review, 3(1), 103-119.

Burger, J. D., \& Warnock, F. E. (2003). Diversification, original sin and international bond portfolios. SSRN Working Paper Series.

Burger, J., \& Warnock, F. (2007). Foreign participation in local currency bond markets. Review of Financial Economics, 16(3), 291-304.

Chan, K., Covrig, V., \& Ng, L. (2005). What Determines the Domestic Bias and Foreign Bias? Evidence from Mutual Fund Equity Allocations Worldwide. The Journal of Finance, 60(3), 1495-1534.

Coeurdacier, N., \& Martin, P. (2009). The geography of asset trade and the euro: Insiders and outsiders. Journal of the Japanese and International Economies, 23(2), 90-113.

Cooper, I., \& Kaplanis, E. (1994). Home bias in equity portfolios, inflation hedging, and international capital market equilibrium. Review of Financial Studies, 7(1), 45-60.

De Santis, R. A. (2010). The Geography of International Portfolio Flows, International CAPM, and the Role of Monetary Policy Frameworks. International Journal of Central Banking, 6(2), 147-197.

De Santis, R. A., \& Gérard, B. (2009). International portfolio reallocation: Diversification benefits and European monetary union. European Economic Review, 53(8), 1010-1027.

Doidge, C., Karolyi, A. G., \& Stulz, R. M. (2007). Why do countries matter so much for corporate governance? Journal of Financial Economics, 86(1), 1-39.

Edison, H. J., \& Warnock, F. E. (2003). A simple measure of the intensity of capital controls. Journal of Empirical Finance, 10(1-2), 81-103.

Eichengreen, B., \& Luengnaruemitchai, P. (2006). Why Doesn't Asia Have Bigger Bond Markets. In Bank for International Settlements (Ed.), Asian Bond Markets: Issues and Prospects (pp. 40-77).

Eichengreen, B., Borensztein, E., \& Panizza, U. (2006). A Tale of Two Markets : Bond Market Development in East Asia and Latin America. Reproduction. Hong Kong Institute for Monetary Research. 
Fidora, M., Fratzscher, M., \& Thimann, C. (2007). Home bias in global bond and equity markets: The role of real exchange rate volatility. Journal of International Money and Finance, 26(4), 631-655.

Gelos, G. R., \& Wei, S.-J. (2005). Transparency and International Portfolio Holdings. The Journal of Finance, 60(6), 2987-3020.

Hahm, J.-H., \& Shin, K. (2009). Complementarity among international asset holdings. Journal of the Japanese and International Economies, 23(1), 37-55.

Karolyi, G. A., \& Stulz, R. M. (2003). Are Financial Assets Priced Locally or Globally? In G. M. Constantinides, M. Harris, \& R. M. Stulz (Eds.), Handbook of the Economics of Finance (pp. 975-1020).

Kaufmann, D., Kraay, A., \& Mastruzzi, M. (2009). Governance Matters VIII: Aggregate and Individual Governance Indicators, 1996-2008. SSRN Working Paper Series.

Kho, B.-C., Stulz, R. M., \& Warnock, F. E. (2009). Financial Globalization, Governance, and the Evolution of the Home Bias. Journal of Accounting Research, 47(2), 597-635.

Lane, P. (2006). Global bond portfolios and EMU. International Journal of Central Banking, 2(2), 1-23.

Levine, R., \& Zervos, S. (1998). Stock Markets, Banks, and Economic Growth. American Economic Review, 88(3), 537-558.

Levy, H., \& Lerman, Z. (1988). The Benefits of International Diversification in Bonds. Financial Analysts Journal, 44(5), 56-64.

Lewis, K. K. (1999). Trying to Explain Home Bias in Equities and Consumption. Journal of Economic Literature, 37(2), 571-608.

McCauley, R., \& Remolona, E. (2000). Size and liquidity of government bond markets. BIS Quarterly Review.

Schoenmaker, D., \& Bosch, T. (2008). Is the Home Bias in Equities and Bonds Declining in Europe ? Investment Management and Financial Innovations, 5(4), 90-102.

Sercu, Piet. (1980). A Generalization of the International Asset Pricing Model. Revue de l'Association Française de Finance, 1(1), 91-135.

Sercu, P., \& Vanpee, R. (2008). Estimating the Costs of International Equity Investments. Review of Finance, 12(4), 587-634.

Sercu, Piet, \& Vanpée, R. (2012). The Home Bias Puzzle in Equity Portfolios. In H. K. Baker \& L. A. Riddick (Eds.), Survey of International Finance. Oxford University Press.

Solnik, B. H. (1974). An Equilibrium Model of the International Capital Market. Journal of Economic Theory, 8(4), 500-524. 
Figure 1 Equity and bond home bias: OECD versus EMs
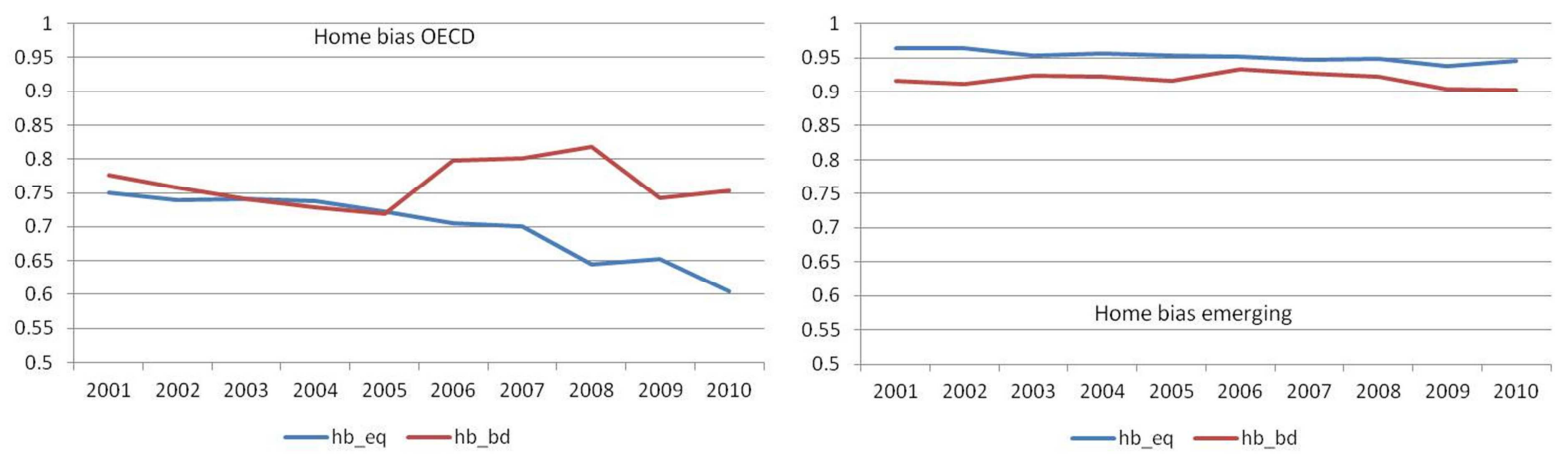

This figure shows the average equity and bond home bias for the period 2001 to 2010 for

OECD countries and EMs. The home bias measures used are those from Equation (1) and (2).

The countries included are listed in Table 1.

Figure 2 Home bias and government debt to GDP: Greece versus Russia
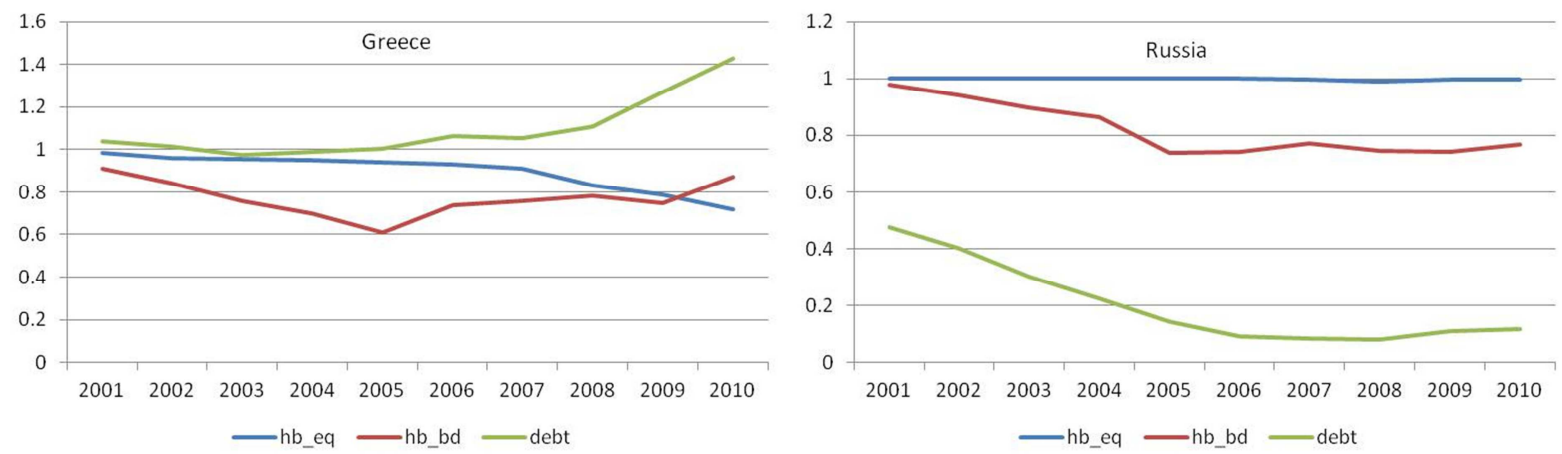

This figure shows the equity and bond home bias and the government debt to GDP for the period 2001 to 2010 for Greece and Russia. The home bias measures used are those from Equation (1) and (2). 
Table 1 Equity and Bond Home Bias 2010

\begin{tabular}{l|cc|cc}
\hline & \multicolumn{2}{|c|}{ Equity home bias } & \multicolumn{2}{c}{ Bond home bias } \\
\hline Country & Unscaled & Scaled & Unscaled & Scaled \\
\hline Argentina & $84.4 \%$ & $84.5 \%$ & $91.2 \%$ & $91.3 \%$ \\
Australia & $78.9 \%$ & $81.3 \%$ & $87.1 \%$ & $88.7 \%$ \\
Austria & $47.9 \%$ & $48.1 \%$ & $58.6 \%$ & $59.1 \%$ \\
Belgium & $42.4 \%$ & $42.6 \%$ & $55.3 \%$ & $55.8 \%$ \\
Brazil & $95.8 \%$ & $98.9 \%$ & $97.7 \%$ & $99.4 \%$ \\
Canada & $71.3 \%$ & $74.5 \%$ & $90.1 \%$ & $92.3 \%$ \\
Chile & $79.0 \%$ & $79.5 \%$ & $78.2 \%$ & $78.3 \%$ \\
Colombia & $96.5 \%$ & $96.9 \%$ & $92.6 \%$ & $92.7 \%$ \\
Czech Rep. & $71.8 \%$ & $71.9 \%$ & $86.6 \%$ & $86.7 \%$ \\
Denmark & $54.5 \%$ & $54.8 \%$ & $76.9 \%$ & $77.7 \%$ \\
Egypt & $99.7 \%$ & $99.9 \%$ & $99.7 \%$ & $99.8 \%$ \\
Finland & $47.3 \%$ & $47.5 \%$ & $39.3 \%$ & $39.4 \%$ \\
France & $62.0 \%$ & $64.5 \%$ & $58.9 \%$ & $62.6 \%$ \\
Germany & $48.5 \%$ & $49.9 \%$ & $54.2 \%$ & $57.3 \%$ \\
Greece & $71.8 \%$ & $71.9 \%$ & $86.7 \%$ & $87.3 \%$ \\
Hong Kong & $81.7 \%$ & $86.4 \%$ & $31.2 \%$ & $31.3 \%$ \\
Hungary & $60.5 \%$ & $60.5 \%$ & $97.7 \%$ & $97.8 \%$ \\
India & $96.6 \%$ & $99.9 \%$ & $99.1 \%$ & $100.0 \%$ \\
Indonesia & $99.0 \%$ & $99.7 \%$ & $97.0 \%$ & $97.1 \%$ \\
Israel & $83.6 \%$ & $83.9 \%$ & $90.1 \%$ & $90.3 \%$ \\
Italy & $53.5 \%$ & $54.2 \%$ & $81.0 \%$ & $85.0 \%$ \\
Japan & $75.5 \%$ & $82.3 \%$ & $69.0 \%$ & $82.3 \%$ \\
Korea & $89.8 \%$ & $91.8 \%$ & $96.1 \%$ & $97.5 \%$ \\
Malaysia & $93.1 \%$ & $93.8 \%$ & $96.0 \%$ & $96.3 \%$ \\
Mexico & $98.6 \%$ & $99.5 \%$ & $98.6 \%$ & $99.2 \%$ \\
Netherlands & $33.5 \%$ & $34.0 \%$ & $62.1 \%$ & $64.2 \%$ \\
New Zealand & $47.3 \%$ & $47.3 \%$ & $82.3 \%$ & $82.4 \%$ \\
Norway & $34.5 \%$ & $34.7 \%$ & $45.0 \%$ & $45.2 \%$ \\
Philippines & $99.6 \%$ & $99.9 \%$ & $95.7 \%$ & $95.8 \%$ \\
Poland & $96.0 \%$ & $96.3 \%$ & $99.0 \%$ & $99.3 \%$ \\
Portugal & $55.5 \%$ & $55.8 \%$ & $64.7 \%$ & $65.1 \%$ \\
Russia & $97.6 \%$ & $99.6 \%$ & $76.6 \%$ & $76.8 \%$ \\
Singapore & $61.2 \%$ & $61.7 \%$ & $56.3 \%$ & $56.5 \%$ \\
South Africa & $86.5 \%$ & $88.3 \%$ & $96.4 \%$ & $96.6 \%$ \\
Spain & $86.9 \%$ & $89.0 \%$ & $82.1 \%$ & $85.0 \%$ \\
Sweden & $54.5 \%$ & $55.1 \%$ & $74.4 \%$ & $75.0 \%$ \\
Switzerland & $58.3 \%$ & $59.8 \%$ & $35.9 \%$ & $36.1 \%$ \\
Thailand & $97.5 \%$ & $98.0 \%$ & $94.5 \%$ & $94.7 \%$ \\
Turkey & $99.2 \%$ & $99.9 \%$ & $98.9 \%$ & $99.2 \%$ \\
United Kingdom & $55.0 \%$ & $58.7 \%$ & $60.7 \%$ & $64.6 \%$ \\
United States & $43.7 \%$ & $66.9 \%$ & $57.7 \%$ & $91.6 \%$ \\
Venezuela & $98.7 \%$ & $98.7 \%$ & $94.6 \%$ & $94.7 \%$ \\
\hline & & & & \\
& & & & \\
& & & & \\
& & & &
\end{tabular}

This table shows the equity and bond home bias for the year 2010 of 42 countries. The unscaled home bias measures are those from Equation (1) and (2). The scaled home bias measures are those from Equation (3) 
Table 2 Home bias regressions

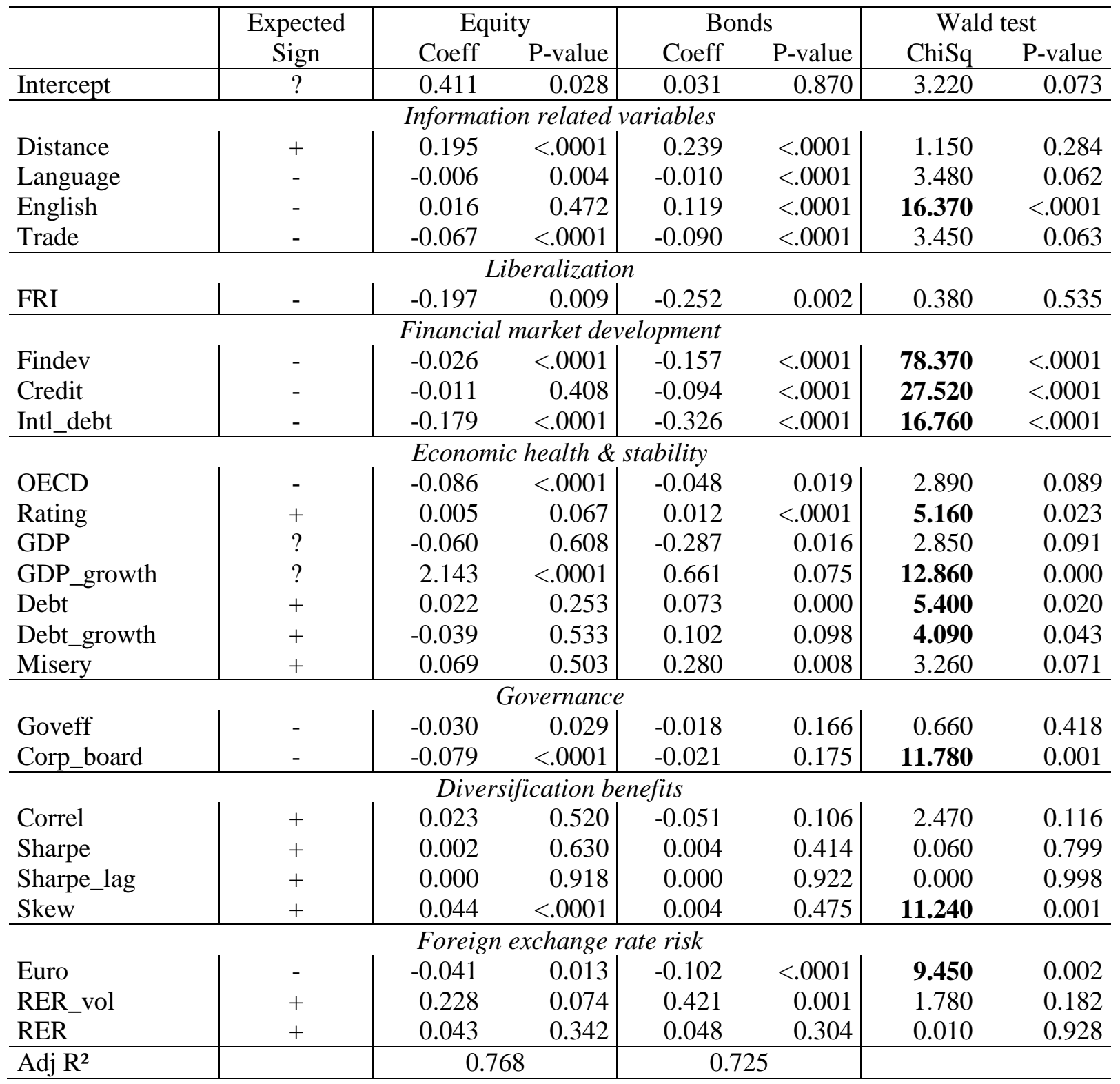

This table contains the SUR estimation results for the home bias regressions as specified in equation (8) for the full sample of 42 countries, over the period 2001-2010. Time dummies for the years 2001 to 2009 are added to the regression specification (not shown in the table as all time-dummy coefficients are insignificant). The last two columns show the Wald test statistics for the coefficient equality test on the corresponding explanatory variables 
Table 3 Foreign bias regressions

\begin{tabular}{|c|c|c|c|c|c|c|c|}
\hline & \multirow{2}{*}{$\begin{array}{c}\text { Expected } \\
\text { Sign }\end{array}$} & \multicolumn{2}{|c|}{ Equity } & \multicolumn{2}{|c|}{ Bonds } & \multicolumn{2}{|c|}{ Wald test } \\
\hline & & Coeff & P-value & Coeff & P-value & ChiSq & P-value \\
\hline Intercept & $?$ & -0.679 & $<.0001$ & -0.096 & 0.252 & 36.77 & $<.0001$ \\
\hline \multicolumn{8}{|c|}{ Information related variables } \\
\hline Distance & + & 0.305 & $<.0001$ & 0.266 & $<.0001$ & 15.01 & 0.000 \\
\hline Language & - & -0.063 & $<.0001$ & -0.080 & $<.0001$ & 1.88 & 0.170 \\
\hline English & - & -0.060 & $<.0001$ & 0.066 & $<.0001$ & 91.14 & $<.0001$ \\
\hline Trade & - & -1.216 & $<.0001$ & -1.545 & $<.0001$ & 4.21 & 0.040 \\
\hline \multicolumn{8}{|c|}{ Liberalization } \\
\hline FRI_host & - & -0.160 & $<.0001$ & -0.119 & 0.006 & 0.75 & 0.387 \\
\hline FRI_home & - & -0.115 & $<.0001$ & -0.023 & 0.529 & 5.16 & 0.023 \\
\hline \multicolumn{8}{|c|}{ Financial market development } \\
\hline Findev_host & - & -0.022 & $<.0001$ & -0.061 & $<.0001$ & 89.53 & $<.0001$ \\
\hline Credit_host & - & 0.011 & 0.086 & -0.033 & 0.000 & 18.88 & $<.0001$ \\
\hline Intl_debt_host & - & -0.078 & $<.0001$ & -0.152 & $<.0001$ & 10.15 & 0.001 \\
\hline \multicolumn{8}{|c|}{ Economic health \& stability } \\
\hline OECD_host & - & 0.008 & 0.317 & 0.077 & $<.0001$ & 29.58 & $<.0001$ \\
\hline OECD_home & - & -0.100 & $<.0001$ & -0.084 & $<.0001$ & 2.51 & 0.113 \\
\hline GDP_host & $?$ & -2.091 & $<.0001$ & -1.388 & $<.0001$ & 58.28 & $<.0001$ \\
\hline GDP_home & $?$ & -1.521 & $<.0001$ & -1.436 & $<.0001$ & 1.31 & 0.252 \\
\hline GDP_growth & $?$ & 0.164 & 0.310 & -0.328 & 0.104 & 4.35 & 0.037 \\
\hline Rating_host & + & -0.012 & $<.0001$ & 0.005 & 0.003 & 80.75 & $<.0001$ \\
\hline Debt_host & + & -0.025 & 0.039 & 0.076 & $<.0001$ & 54.82 & $<.0001$ \\
\hline Debt_home & + & 0.028 & 0.008 & 0.058 & $<.0001$ & 6.00 & 0.014 \\
\hline Debt_host_growth & + & 0.068 & 0.018 & 0.143 & 0.000 & 3.18 & 0.075 \\
\hline Debt_home_growth & + & 0.018 & 0.444 & 0.225 & $<.0001$ & 31.60 & $<.0001$ \\
\hline Misery & + & 0.251 & $<.0001$ & 0.142 & 0.012 & 2.90 & 0.089 \\
\hline \multicolumn{8}{|c|}{ Governance } \\
\hline Goveff & - & -0.064 & $<.0001$ & 0.007 & 0.210 & 75.47 & $<.0001$ \\
\hline Corp_board & - & -0.055 & $<.0001$ & 0.002 & 0.773 & 26.74 & $<.0001$ \\
\hline \multicolumn{8}{|c|}{ Diversification benefits } \\
\hline Correl & + & -0.135 & $<.0001$ & -0.064 & $<.0001$ & 14.20 & 0.000 \\
\hline Sharpe & - & -0.004 & 0.020 & -0.006 & 0.008 & 1.14 & 0.285 \\
\hline Sharpe_lag & - & 0.000 & 0.959 & 0.014 & $<.0001$ & 27.30 & $<.0001$ \\
\hline Skew & - & 0.002 & 0.722 & 0.009 & 0.012 & 1.67 & 0.196 \\
\hline \multicolumn{8}{|c|}{ Foreign exchange rate risk } \\
\hline Euro & - & -0.170 & $<.0001$ & -0.190 & $<.0001$ & 1.26 & 0.263 \\
\hline RER_vol & + & 0.175 & 0.000 & 0.325 & $<.0001$ & 88.50 & $<.0001$ \\
\hline RER & + & 0.052 & 0.000 & 0.132 & $<.0001$ & 13.26 & 0.000 \\
\hline Adj $R^{2}$ & & \multicolumn{2}{|c|}{0.392} & \multicolumn{2}{|c|}{0.221} & & \\
\hline
\end{tabular}

This table contains the SUR estimation results for the foreign bias regressions as specified in equation (10) for the full sample of 42 countries, over the period 2001-2010. Time dummies could not be included in the foreign bias regressions due to singularities in the model. The last two columns show the Wald test statistics for the coefficient equality-test on the corresponding explanatory variables. 
Appendix Table A1: Country classification

\begin{tabular}{ll}
\hline OECD & Emerging \\
\hline Australia & Argentina \\
Austria & Brazil \\
Belgium & Chile* \\
Canada & Colombia \\
Czech Republic & Egypt \\
Denmark & Hong Kong \\
Finland & India \\
France & Indonesia \\
Germany & Israel* \\
Greece & Malaysia \\
Hungary & Philippines \\
Italy & Russia \\
Japan & Singapore \\
Korea, South & South Africa \\
Mexico & Thailand \\
Netherlands & Venezuela \\
New Zealand & \\
Norway & \\
Poland & \\
Portugal & \\
Spain & \\
Sweden & \\
Switzerland & \\
Turkey & \\
United Kingdom & \\
United States & \\
\hline
\end{tabular}

*Chile and Israel became OECD member countries in 2010. 
Table A2 Home bias regressions, traditional home bias measure as dependent variable

\begin{tabular}{|c|c|c|c|c|c|c|c|}
\hline \multirow{3}{*}{$\overline{\text { Intercept }}$} & \multirow{3}{*}{$\begin{array}{c}\text { Expected } \\
\text { Sign }\end{array}$} & \multicolumn{2}{|c|}{ Equity } & \multicolumn{2}{|c|}{ Bonds } & \multicolumn{2}{|c|}{ Wald test } \\
\hline & & Coeff & p-value & Coeff 1 & $\mathrm{p}$-value & test stat & $\operatorname{Pr}>\mathrm{ChiSq}$ \\
\hline & & 0.417 & 0.026 & 0.135 & 0.475 & 1.840 & 0.175 \\
\hline \multicolumn{8}{|c|}{ Information related variables } \\
\hline Distance & + & 0.196 & $<.0001$ & 0.220 & $<.0001$ & 0.350 & 0.556 \\
\hline Language & - & -0.006 & 0.004 & -0.009 & $<.0001$ & 2.300 & 0.129 \\
\hline English & - & 0.010 & 0.653 & 0.118 & $<.0001$ & 18.860 & $<.0001$ \\
\hline Trade & - & -0.068 & $<.0001$ & -0.095 & $<.0001$ & 4.670 & 0.031 \\
\hline \multicolumn{8}{|c|}{ Liberalization } \\
\hline FRI & - & -0.195 & 0.010 & -0.236 & 0.004 & 0.220 & 0.637 \\
\hline \multicolumn{8}{|c|}{ Financial market development } \\
\hline Findev & - & -0.022 & $<.0001$ & -0.152 & $<.0001$ & 77.690 & $<.0001$ \\
\hline Credit & - & -0.011 & 0.412 & -0.094 & $<.0001$ & 28.510 & $<.0001$ \\
\hline Intl_debt & - & -0.177 & $<.0001$ & -0.319 & $<.0001$ & 16.410 & $<.0001$ \\
\hline \multicolumn{8}{|c|}{ Economic health \& stability } \\
\hline OECD & - & -0.087 & $<.0001$ & -0.048 & 0.019 & 2.940 & 0.087 \\
\hline Rating & + & 0.003 & 0.208 & 0.011 & 0.000 & 5.860 & 0.016 \\
\hline GDP & $?$ & -0.977 & $<.0001$ & -1.446 & $<.0001$ & 12.680 & 0.000 \\
\hline GDP_growth & $?$ & 2.119 & $<.0001$ & 0.702 & 0.061 & 12.320 & 0.000 \\
\hline Debt & + & -0.012 & 0.535 & 0.072 & 0.000 & 7.990 & 0.005 \\
\hline Debt_growth & + & -0.037 & 0.561 & 0.104 & 0.091 & 4.280 & 0.039 \\
\hline Misery & + & 0.073 & 0.482 & 0.260 & 0.013 & 2.720 & 0.099 \\
\hline \multicolumn{8}{|c|}{ Governance } \\
\hline Goveff & - & -0.035 & 0.011 & -0.022 & 0.091 & 0.780 & 0.376 \\
\hline Corp_board & - & -0.079 & $<.0001$ & -0.021 & 0.174 & 12.220 & 0.001 \\
\hline \multicolumn{8}{|c|}{ Diversification benefits } \\
\hline Correl & + & 0.028 & 0.428 & -0.051 & 0.106 & 2.850 & 0.091 \\
\hline Sharpe & + & 0.002 & 0.664 & 0.003 & 0.540 & 0.020 & 0.888 \\
\hline Sharpe_lag & + & 0.000 & 0.987 & 0.000 & 0.966 & 0.000 & 0.965 \\
\hline Skew & + & 0.043 & $<.0001$ & 0.003 & 0.552 & 11.360 & 0.001 \\
\hline \multicolumn{8}{|c|}{ Foreign exchange rate risk } \\
\hline Euro & - & -0.038 & 0.023 & -0.098 & $<.0001$ & 9.600 & 0.002 \\
\hline RER_vol & + & 0.179 & 0.160 & 0.366 & 0.005 & 1.750 & 0.185 \\
\hline RER & + & 0.046 & 0.306 & 0.050 & 0.281 & 0.010 & 0.936 \\
\hline Adj R ${ }^{2}$ & & \multicolumn{2}{|c|}{\begin{tabular}{l|l}
0.789 \\
\end{tabular}} & \multicolumn{2}{|c|}{0.738} & & \\
\hline
\end{tabular}


Table A3 Foreign bias regressions, traditional foreign bias as dependent variable

\begin{tabular}{|c|c|c|c|c|c|c|c|}
\hline & \multirow{2}{*}{$\begin{array}{c}\text { Expected. } \\
\text { Sign }\end{array}$} & \multicolumn{2}{|c|}{ Equity } & \multicolumn{2}{|c|}{ Bond } & \multicolumn{2}{|c|}{ Wald } \\
\hline & & Coeff & $\mathrm{p}$-value & Coeff & $\mathrm{p}$-value & Statistic & p-value \\
\hline Intercept & $?$ & -0.0205 & $<.0001$ & -0.0559 & $<.0001$ & 105.17 & $<.0001$ \\
\hline \multicolumn{8}{|c|}{ Information related variables } \\
\hline Distance & + & 0.0026 & $<.0001$ & 0.0034 & $<.0001$ & 4.43 & 0.035 \\
\hline Language & - & -0.0030 & $<.0001$ & -0.0031 & $<.0001$ & 0.08 & 0.773 \\
\hline English & - & 0.0079 & $<.0001$ & -0.0050 & $<.0001$ & 751.46 & $<.0001$ \\
\hline Trade & - & -0.1042 & $<.0001$ & -0.1269 & $<.0001$ & 15.76 & $<.0001$ \\
\hline \multicolumn{8}{|c|}{ Liberalization } \\
\hline FRI_host & - & -0.0124 & $<.0001$ & -0.0187 & $<.0001$ & 12.55 & 0.000 \\
\hline FRI_home & - & -0.0095 & $<.0001$ & -0.0031 & 0.010 & 19.46 & $<.0001$ \\
\hline \multicolumn{8}{|c|}{ Financial market development } \\
\hline Findev_host & - & -0.0015 & $<.0001$ & -0.0051 & $<.0001$ & 154.31 & $<.0001$ \\
\hline Credit_host & - & -0.0032 & $<.0001$ & -0.0050 & $<.0001$ & 493.92 & $<.0001$ \\
\hline Intl_debt_host & - & -0.0053 & $<.0001$ & -0.0075 & $<.0001$ & 7.34 & 0.007 \\
\hline \multicolumn{8}{|c|}{ Economic health \& stability } \\
\hline OECD_host & - & 0.0005 & 0.291 & -0.0006 & 0.077 & 5.79 & 0.016 \\
\hline OECD_home & - & -0.0044 & $<.0001$ & -0.0006 & 0.062 & 105.89 & $<.0001$ \\
\hline GDP_host & ? & 1.0813 & $<.0001$ & 1.1417 & $<.0001$ & 342.44 & $<.0001$ \\
\hline GDP_home & $?$ & 0.0078 & 0.005 & 0.0044 & 0.046 & 1.67 & 0.196 \\
\hline GDP_growth & $?$ & 0.0559 & $<.0001$ & 0.0621 & $<.0001$ & 0.50 & 0.481 \\
\hline Rating_host & + & 0.0005 & $<.0001$ & 0.0012 & $<.0001$ & 115.86 & $<.0001$ \\
\hline Debt_host & + & -0.0101 & $<.0001$ & 0.0086 & $<.0001$ & 1487.00 & $<.0001$ \\
\hline Debt_home & + & -0.0005 & 0.286 & 0.0002 & 0.561 & 2.52 & 0.112 \\
\hline Debt_host_growth & + & 0.0069 & $<.0001$ & 0.0050 & $<.0001$ & 1.51 & 0.218 \\
\hline Debt_home_growth & + & 0.0020 & 0.144 & 0.0036 & 0.001 & 18.28 & $<.0001$ \\
\hline Misery & + & 0.0046 & 0.058 & 0.0047 & 0.013 & 0.00 & 0.954 \\
\hline \multicolumn{8}{|c|}{ Governance } \\
\hline Goveff & - & -0.0031 & $<.0001$ & -0.0012 & $<.0001$ & 35.69 & $<.0001$ \\
\hline Corp_board & - & -0.0022 & $<.0001$ & -0.0013 & 0.001 & 5.70 & 0.017 \\
\hline \multicolumn{8}{|c|}{ Diversification benefits } \\
\hline Correl & + & -0.0095 & $<.0001$ & -0.0040 & $<.0001$ & 51.15 & $<.0001$ \\
\hline Sharpe & - & 0.0001 & 0.236 & 0.0003 & 0.000 & 3.74 & 0.053 \\
\hline Sharpe_lag & - & -0.0005 & $<.0001$ & -0.0002 & 0.012 & 8.57 & 0.003 \\
\hline Skew & - & -0.0012 & $<.0001$ & -0.0003 & 0.004 & 12.53 & 0.000 \\
\hline \multicolumn{8}{|c|}{ Foreign exchange rate risk } \\
\hline Euro & - & -0.0076 & $<.0001$ & -0.0149 & $<.0001$ & 128.68 & $<.0001$ \\
\hline RER_vol & + & -0.0201 & $<.0001$ & 0.0028 & 0.067 & 147.54 & $<.0001$ \\
\hline RER & + & -0.0002 & 0.765 & 0.0002 & 0.701 & 0.39 & 0.530 \\
\hline Adj $R^{2}$ & & \multicolumn{2}{|c|}{0.909} & \multicolumn{2}{|c|}{0.950} & & \\
\hline
\end{tabular}

